\title{
The Challenge of the Use the Microorganisms in Enhance Oil Recover
}

\author{
Xisto Oliveira $\mathrm{LK}^{1}$ and Santos $\mathrm{SN}^{2 *}$ \\ ${ }^{1}$ Federal Center for Technological, Education of Bahia, Brazil \\ ${ }^{2}$ Laboratoryof Environmental Microbiology, Brazilian Agricultural Research Corporation-EMBRAPA, Brazil \\ Submission: May 2, 2017; Published: May 30, 2017 \\ *Corresponding author: Suikinai Nobre Santos, Brazilian Agricultural Research Corporation-EMBRAPA, Laboratoryof Environmental \\ Microbiology, Rod SP 340, Km 127, 5 CEP 13820-000, São Paulo, Brazil, Tel: +55193311 2665; Fax: +55193311 2640; Email: suikinai@gmail.com
}

Keywords: Microbial Enhanced Oil Recovery; Crude Oil Recovery; Oil Production; Microbial Bio Prospecting

\section{Introduction}

Energy is the key to the development of any society. Energy sources derived from fossil fuels are still hold the largest share of energy generation for society. So far, there are no many options for renewable sources and/or large-scale green products for total replacement of this source.The produce from these resources by currently used methods leads to only 8-50\% recovery of the total oil present in the reservoir. There is a great need of efficient advanced methods of recovery of fossil fuel, to improve upon the recovery of trapped crude oil, which becomes inaccessible by traditional techniques [1].

Conventional oil production occurs in three stages: Primary oil recovery is the result of natural internal reservoir pressure which exists within the formation, harvests only 30 $40 \%$ of the original oil in place (OOIP) Patel et al. [2]. When this internal driving force diminishes to a point at which oil production decline, then secondary recovery methods follow in the form of water flooding, which continues until the ration of oil produced to water injected yields more water than oil, after which the process becomes uneconomical to separate oil from the oil - water mixture [3]. Enhanced recovery methods include the introduction of fluids to physically displace the OOPI to make it easier to recovery. It is estimated such secondary recovery methods will recoup about $15-25 \%$ of the OOIP Belyaev et al. [4], Lazar et al. [5], McInerney et al. [6]; Van Hamme et al. [7], Patel et al. 2015. This residual oil is usually the target of many enhanced oil recovery technology and it amounts to about 2-4 trillions barrels Hall et al. [8], [9]. Around $67 \%$ of the total oil reserves Bryant et al. [10]. The tertiary recovery methods involving chemical or thermal energy, which chemical flooding includes use of alkaline water floods, carbon dioxide flooding, and polymer flooding? Thermal recovery includes in situ combustion and the injection of steam. But all these recovery methods suffer from technological problems and money constraints [1].

While the application of biotechnology to enhanced oil recovery cannot solve our global need for renewable energy sources, microbial enhanced oil recovery (MEOR) can allow us to obtain more oil in eco-friendly ways and tilt the global energy balance towards lower prices and more domestic production Shibulal et al. [11]. Microbial Enhance Oil Recovery (MEOR) is a combination of methods that use microorganism sand their metabolic products in petroleum reservoirs to enhance the amount of oil that can be produced [12], Yen [5], Zhang \& Xiang. This technique has the potential to be cost-efficient in the extraction of oil remained trapped in capillary pores of the formation rock or in areas not swept by classical or modern enhanced oil recovery (EOR) methods, such as combustion, steams, miscible displacement, caustic surfactant-polymers flooding [5]. In addition, there are two major strategies are normally employed in MEOR, the first one is a bacteria injection normally referred to as "traditional" MEOR method with nutrients and the second method involves simulation of indigenous bacteria through injection of nutrients ().The MEOR application can be in a form of cyclic (single well simulation), microbial flooding recovery or selective plugging recovery Zhang \& Xiang.

Beckman introduced bio prospecting into microorganisms and of their respective bio products for oil recovery, since 1926. In addition, Zobell et al. [13], [14] published in their studies the main mechanisms responsible for oil release from porous media involving processes such as dissolution of inorganic 
carbonates by bacterial metabolites, production of bacterial gases, which decrease the viscosity of oil, thereby promoting its flow; as well as the high affinity of bacteria for solids, later attached to crowd off the oil films. Earlier studies identified the need to improve critical information on mechanisms, metabolic rates and required concentrations of microbial products. Some of these have been described [15-18].

The microorganism candidate to fulfill this purpose, supposed to be adequate production of required metabolites to reduction of surface tension and interfacial tension between oil and water, such as: acids (Clostridiumsp., Enterobacter) to increase of the permeability of the reservoir by dissolution of the rock by organic acids, gases (Enterobacter, Clostridium sp.) when excreted are immediately incorporated into the crude, promoting and re-establishing gas drive in the reservoir, solvents (Clostridium acetobutylicum, Zymomomas mobilis) to dissolution of organic deposits, biomass (Bacillus lichenifonnis, Xanthomonas campestris), biosurfactans, (Acinetobacter calcoacticus, Arthrobacter paraffineus, Pseudomonas sp.) to decrease of viscosity and biopolymers (B. polymyxa, Brevibacterium viscogenes)to selective obstruction of regions of high permeability Torres et al. [18]; Patel et al.

The physic-chemical parameters in the reservoir will be determinate to select of bacteria withstand the extreme reservoir conditions, and some of them are considered as limiting for successful application of MEOR: salinity, temperature pressure, $\mathrm{pH}$, pore size, nutrients, redox potential etc. All these factors can affects growth of bacteria, proliferation, metabolism and survival and limit their ability to produce desired quantities of metabolites needed for enhanced oil recovery Maudgalya et al. [19] [18]. Another alternative that has been explored to overcome this difficulty, it will be the application of the genetic engineering tools to develop more effective bacteria that may subsist on inexpensive and abundant nutrients.

It is known that among the more robust crude oil recovery techniques used are not sufficient to fully exploit existing reserves, but recovery around $50 \%$ of the original-oil-in-place in an oil field coupled with an annual capacity, with declines of between $5-20 \%$ in mature fields, many more oil companies and agencies are starting to open their minds to the possibility of using MEOR permanently. Then, there is a clear need to complementary research and development in order to mitigate factors and constraints, as well as to develop more advanced and effective recovery processes with exploitation of the microbial potential. The challenge in all cases is to move these technologies more rapidly from the laboratory to the field.

\section{References}

1. Khire JM, Khan MI (1994) microbial enhanced oil recovery. Enzyme Microb Technol (16).
2. Sen R (2008) Biotechnology in petroleum recovery: the microbial EOR. Prog Energy Combust Sci 34(6): 714-24.

3. Ohimain E (2010) Petroleum Geomicrobiology. Chaper 5 In Geomicrobiology, Ed by Sudhir K Jain, Abdul Arif Khan and Mahendra K Rai, Science Publishers pp.139-174.

4. Belyaev S, et al. (2004) Use of microorganisms in the biotechnology for the enhancement of oil recovery. Microbiology 73(5): 590-598.

5. Lazar I, Petrisor IG, Yen TF (2007) Microbial Enhanced Oil Recovery (MEOR). Petroleum Science and Technology 25(11): 1353-1366.

6. McInerney M, Nagle DP, Knapp RM (2005) microbially enhanced oil recovery: past, present, and future. Magot M, Ollivier B (Eds.), Petroleum microbiology pp. 215-237.

7. Van Hamme JD, Singh A, Ward OP (2003) Recent advances in petroleum micro- biology. Microbiol Mol Biol Rev 67 (4): 503-549.

8. Hall C, Tharakan P, Hallock J, Cleveland C, Jefferson M, et al. (2003) Hydrocarbons and the evolution of human culture. Nature 426(6964): 318-322.

9. Sylvester O, Bibobra I (2014) Adjustment to Oil Saturation Estimate Due to Various Reservoir Drive Mechanisms. Int J of Advan Petrol Engi and Tech (I1): 17-26.

10. Bryant S, Lockhart TP (2000) Reservoir engineering analysis of microbial enhanced oil recovery. In Proceedings of the SPE Annual Technical Conference and Exhibition 5(5): 10.

11. Shibulal B, Al-Bahry SN, Al-Wahaibi YM, Abdulkader E, Al-Bemani AS, et al. (2014) Microbial Enhanced Heavy Oil Recovery by the Aid of Inhabitant Spore-Forming Bacteria: An Insight Review. The Scientific World Journal 2014(2014): 12.

12. Rebeka S (1987) Potential uses of microorganisms in petroleum recovery technology. Proceedings of the Oklahoma Academy of Science.

13. Zobell CE (1947a) Bacterial release of oil from oil-bearing materials, part I. World Oil 126: 36-47.

14. Zobell CE (1947b) Bacterial release of oil from oil-bearing materials, part II. World Oil 127: 35-41.

15. Brown LR, Vadie AA (2002) Slowing production decline and extending the enhanced oil recovery. SPE-63229 presented at ATCE, Dallas, Texas, USA, pp.1-4.

16. Bryant SL, Lockhart TP (2002) Reservoir engineering analysis of microbial economic life of an oil field: New MEOR technology. SPER eserv EvalEng 5: 33-41.

17. Kowalewski EI, Rues latten K, Bødtker SG, Torsæter O (2006) Microbial improved oil recovery-bacterial induced wettability and interfacial tension effects on oil production. J Petrol Sci Eng 52(1-4): 275-286.

18. Jimoh IA (2012) Microbial enhanced oil recovery. Luma Print 6700 Esbjerg.

19. Maudgalya S, Knapp RM, McInerney MJ (2007) Microbial enhanced oil recovery technologies: A review of the past, present and future, SPE 106978.

20. Janshekar H (1985) Microbial enhanced oil recovery process. In: Microbes and Oil Recovery. Vol. (Zajic, JE and Donaldson, 22 E C eds) Bio resource Publications 23: 39-53.

21. Beckmann J (1926) Action of bacteria on mineral oil. Ind Eng Chem News Ed, 4: 3W. 


\section{Recent Advances in Petrochemical Science}

his work is licensed under Creative

Your next submission with Juniper Publishers will reach you the below assets

- Quality Editorial service

- Swift Peer Review

- Reprints availability

- E-prints Service

- Manuscript Podcast for convenient understanding

- Global attainment for your research

- Manuscript accessibility in different formats ( Pdf, E-pub, Full Text, Audio)

- Unceasing customer service

Track the below URL for one-step submission https://juniperpublishers.com/online-submission.php 